\title{
PENGARUH KONSENTRASI DAN RASIO LARUTAN POTASIUM HIDROKSIDA DAN RUMPUT LAUT TERHADAP MUTU KARAGINAN KERTAS
}

\author{
Jamal Basmal, Th. Dwi Suryaningrum dan Yusma Yennie")
}

\begin{abstract}
ABSTRAK
Penelitian perbaikan kualitas karaginan kertas yang diekstrak dari Eucheuma cottonii telah dilakukan dengan melakukan variasi larutan $\mathrm{KOH} 4 \%, 6 \%$, dan $12 \%$. Rasio $E$. cottonii kering berbanding larutan $\mathrm{KOH} 1: 8$ dan $1: 12$. Waktu pemasakan 2 jam pada kisaran suhu $70-80^{\circ} \mathrm{C}$. $E$. cottonii yang telah dimasak tersebut kemudian diekstrak menggunakan air tawar pada suhu antara $90^{\circ}-95^{\circ} \mathrm{C}$ selama 120 menit. Hasil penelitian menunjukkan bahwa larutan $\mathrm{KOH}$ dapat meningkatkan kekuatan gel, menurunkan nilai kekentalan larutan karaginan, menurunkan kadar abu tak larut asam, abu, dan sulfat. Perlakuan terbaik pada penelitian ini ditinjau dari nilai kekuatan gel adalah perlakuan pemasakan rumput laut di dalam larutan $\mathrm{KOH} 12 \%$, dengan perbandingan E. cottonii dan volume larutan $\mathrm{KOH} 1: 8$. Karaginan kertas yang dihasilkan mempunyai karakteristik nilai kekuatan gel sebesar $578,5 \mathrm{~g} / \mathrm{cm}^{2}$, kekentalan $15,0 \mathrm{cPs}$, kadar sulfat $18,1 \%$, abu tak larut asam $0,1 \%$, abu $14,1 \%$, kadar air $9,4 \%$ dan rendemen $29,3 \%$.
\end{abstract}

\section{ABSTRACT: Effect of concentration and ratio of potassium hydroxide solution to sea- weed on quality of sheet carrageenan. By: Jamal Basmal, Th. Dwi Suryaningrum and Yusma Yennie}

\begin{abstract}
Quality improvement of sheet carrageenan extracted from Eucheuma cottonii was carried out using several concentration of hot potassium hydroxide solution $(4 \%, 6 \%$ and $12 \%)$. The ratio of $E$. cottonii to hot potassium hydroxide solution were 1:8 and 1:12. The heating time was 120 minutes at $70^{\circ}-80^{\circ} \mathrm{C}$. Carrageenan was then extracted from the seaweed by cooking in fresh water at $90^{\circ}-$ $95^{\circ} \mathrm{C}$ for 2 hours. It was found that $\mathrm{E}$. cottonii treated with hot potassium hydroxide solution could increase the value of gel-strength and reduce the value of viscosity, ash, acid insoluble ash, and sulphate content. E. cottonii heated in $12 \%$ potassium hydroxide solution with the ratio between $E$. cottonii and potassium hydroxide of 1:8 produced the best sheet carrageenan based on the gelstrength $\left(578.5 \mathrm{~g} / \mathrm{cm}^{2}\right)$, viscosity $(15.0 \mathrm{cPs})$, sulphate content $(18.1 \%)$, ash content $(14.1 \%)$, acid insoluble ash $(0.1 \%)$, moisture content $(9.4 \%)$ and yield $(29.3 \%)$.
\end{abstract}

KEYWORDS: temperature, E. cottonii, KOH solution, sheet carrageenan

\section{PENDAHULUAN}

Karaginofit yang tumbuh dominan di perairan Indonesia adalah rumput laut jenis Eucheuma dan Hypnea. Berdasarkan struktur kimianya karaginan dapat dibagi menjadi 3 jenis yakni: iota, kappa dan lamda-carrageenan. Secara umum struktur molekul karaginan merupakan polisakarida rantai panjang tidak bercabang yang tersusun atas gugus 3,6-anhydro-Dgalaktosa dan gugus sulfat ester. $i$-karaginan dapat diekstrak dari rumput laut jenis $E$. spinosum dan $E$. muricatum, $\mu$-karaginan dihasilkan dari rumput laut jenis Chondrus chondrus yang banyak terdapat di perairan subtropis, dan $k$-karaginan umumnya dihasilkan dari rumput laut jenis $E$. cottonii, E. dule, E (Kappaphycus) alvarezii dan Hypnea. E. cottonii dan E. spinosum dominan tumbuh di perairan Indonesia dan Filipina. Rumput laut penghasil iota yang tumbuh dominan di perairan Indonesia adalah $E$. spinosium yang diperkirakan mencapai $80-90 \%$, sedangkan $K$.alvarezii sebagai penghasil $k$-karaginan mendominasi lahan budidaya di Indonesia (Istini \& Zatnika, 1991)

lota terdiri dari D-galaktosa-4-sulfat dan 3,6anhydro-D-galaktosa-2-sulfat, $\lambda$-carrageenan terdiri dari D-galaktosa-2-sulfat dan D-galaktosa-2,6-disulfat, sedangkan $k$-carrageenan ( $k$-karaginan) merupakan polisakarida yang tersusun dari D-galaktosa-4-sulfat dengan ikatan 1,3 dan 3,6-anhidrous-galaktosa dengan ikatan atom C 1,4 (Towe, 1973). $k$-karaginan dari alga laut terbentuk dari $\mu$-karaginan dengan cara menghilangkan sulfat pada atom $\mathrm{C}-6$ dalam galaktosa

, Peneliti pada Balai Besar Riset Pengolahan Produk dan Bioteknologi Kelautan dan Perikanan 
6-sulfat dengan ikatan atom C 1,4 dan membentuk 3,6-anhidrous-galaktosa (Glicksman, 1983). Reaksi pembentukan $k$-karaginan dari $\mu$-karaginan dapat dilakukan dengan cara menghilangkan sebagian gugus sulfat $\left(\mathrm{OSO}_{3}{ }^{-}\right)$dengan menggunakan borohidrida dalam kondisi alkali (Moirano, 1977).

Disamping menggunakan bahan kimia gugus sulfat dapat pula dihilangkan dengan aktivitas enzim dekinkase pada atom $\mathrm{C}-6$ dari $\mu$-karaginan menjadi 3,6-anhidrous-galaktosa pada $k$-karaginan (Glicksman, 1983).

Karaginan umumnya didapatkan dalam bentuk sodium, potasium atau kombinasi ion-ion tersebut di atas. Ion-ion tersebut sangat menentukan sifat-sifat fisika kimia karaginan. Misalnya potasium karaginan secara komersial adalah campuran antara $\lambda$ - dan $k$ carageenan dan bersifat larut di dalam air hangat, tetapi hanya $k$-karaginan yang membentuk gel. Sodium karaginan larut di dalam air dingin tetapi tidak membentuk gel. Sifat-sifat karaginan adalah thermally reversible. Formasi gel didasarkan atas struktur double helix yang akan menurun pada suhu tinggi. Pada proses pendinginan, polimer network terbentuk dengan formasi pilinan rangkap (double helix) membentuk junction zone yang kemudian mengalami agregasi (Rees, 1969).

Kualitas polisakarida rumput laut sangat bergantung pada parameter ekstraksi seperti suhu, konsentrasi bahan kimia, rasio rumput laut dan media pengekstrak, waktu ekstraksi dan teknik pemisahan polisakarida rumput laut dari bahan lain seperti selulosa, dan garam-garam lain. Semua parameter tersebut akan berpengaruh terhadap nilai kekentalan, daya larut, stabilitas produk, dan kekuatan gel (gel strength) serta nilai kekakuan ( $r$ gidity) (Towle, 1973). Media air sangat berperan penting untuk melarutkan/penarikan polisakarida dari thallus rumput laut. Ketidaktepatan jumlah air yang diberikan selama proses ekstraksi akan bermasalah dalam penarikan polisakarida serta mutu produk yang dihasilkan (Rees, 1969).

$\mathrm{KOH}$ telah dipakai dalam usaha meningkatkan kekuatan gel $k$-karaginan, tetapi pemberian larutan $\mathrm{KOH}$ yang berlebihan selama proses ekstraksi akan menyebabkan proses hidrolisis yang berakibat terjadinya penurunan mutu $k$-karaginan yang dihasilkan (Kirk-Othmer, 1968 dalam Purba, 1997). Selanjutnya dikatakan bahwa fungsi utama $\mathrm{KOH}$ dalam proses ekstraksi $k$-karaginan adalah mereduksi kadar lemak, dan protein. Adanya ion $\mathrm{K}^{+}$berfungsi untuk mengikat gugus sulfat $\left(\mathrm{OSO}_{3}^{-}\right)$. Kekuatan gel karaginan dapat ditingkatkan dengan melakukan proses pemasakan rumput laut di dalam larutan $\mathrm{KOH}$. Istini \& Zatnika (1991) melaporkan bahwa penggunaan konsentrasi larutan $\mathrm{KOH}$ dari $2 \%$ hingga $8 \%$ pada suhu pemanasan $75^{\circ} \mathrm{C}$ dapat meningkatkan kekuatan gel karaginan dari 69,6 menjadi $243,6 \mathrm{~g} / \mathrm{cm}^{2}$. Namun demikian hasil penelitian tersebut belum mencapai maksimum. Istini \& Zatnika (1991) berpendapat bahwa nilai kekuatan gel masih dapat ditingkatkan dengan melakukan variasi konsentrasi larutan $\mathrm{KOH}$ yang lebih tinggi, tetapi dengan memperhatikan batas-batas penambahan yang telah diizinkan dalam makanan. Rasio rumput laut dengan larutan $\mathrm{KOH}$ juga berpengaruh terhadap penetrasi ion $\mathrm{K}^{+} \mathrm{ke}$ dalam thallus rumput laut.

Tujuan penelitian ini adalah mencari rasio rumput laut dengan media air pemasak dan konsentrasi larutan $\mathrm{KOH}$ yang tepat dalam usaha meningkatkan kekuatan gel $k$-karaginan dan meminimalkan kadar abu $k$-karaginan.

\section{BAHAN DAN METODE}

\section{Bahan}

Bahan baku yang digunakan adalah rumput laut Eucheuma cottonii kering petani yang berasal dari pembudidaya rumput laut di Kabupaten Sumenep. Sedangkan bahan pembantu yang digunakan adalah $\mathrm{KOH}$, dan $\mathrm{KCl}$ teknis.

\section{Metode}

Penelitian ini menggunakan rancangan acak lengkap dengan perlakuan konsentrasi $\mathrm{KOH} 4 \%, 6 \%$ dan $12 \%$. Rasio rumput laut dan volume larutan $\mathrm{KOH}$ yang digunakan adalah: 1:8 (b/v) dan 1:12 (b/v) dan dimasak pada kisaran suhu $70^{\circ}-80^{\circ} \mathrm{C}$ selama 2 jam. Untuk mendapatkan data yang akurat percobaan dilakukan dengan tiga kali ulangan.

Proses pembuatan karaginan kertas adalah sbb: rumput laut dimasak pada suhu antara $70^{\circ}-80^{\circ} \mathrm{C}$ selama 2 jam dalam larutan $\mathrm{KOH}$ sesuai dengan konsentrasi perlakuan. Untuk selanjutnya dilakukan proses ekstraksi menggunakan air tawar dengan rasio 1:10. Proses ekstraksi dilakukan pada suhu $90^{\circ}-$ $95^{\circ} \mathrm{C}$ selama 2 jam. Bubur rumput laut yang terbentuk disaring menggunakan saringan kain kasa. Filtrat yang telah dipisahkan dari ampasnya ditambah garam $\mathrm{KCl}$ sebanyak $0,1 \%(\mathrm{~b} / \mathrm{v})$ dari volume filtrat, untuk selanjutnya dijendalkan di dalam pan penjendal selama satu malam. Filtrat yang telah dijendalkan tersebut dipotong-potong, dibungkus dengan kain kasa kemudian dipres untuk mereduksi air selama satu malam. Filtrat rumput laut yang telah dipres tersebut dikeringkan hingga menjadi karaginan kertas.

Untuk mengetahui kualitas karaginan yang dihasilkan dilakukan analisis produk yang meliputi: kadar air, kadar abu tak larut asam, kadar abu 
(Horwitz, 1980), kadar sulfat (Anon., 1986). Parameter fisik yang diuji adalah rendemen, nilai kekentalan yang diukur dari larutan karaginan 1,5\% (b/v) pada suhu $75^{\circ} \mathrm{C}$ dengan menggunakan viskometer merek Brookfields dan kekuatan gel menggunakan prosedur Marine Colloid (1978).

\section{HASIL DAN BAHASAN}

\section{Rendemen}

Kisaran rendemen yang diperoleh pada penelitian ini antara $23,9 \%-29,25 \%$, dengan nilai rendemen tertinggi ditemukan pada perlakuan pemasakan rumput laut dalam larutan $\mathrm{KOH} 12 \%$ dengan rasio rumput laut dan larutan $\mathrm{KOH}$ 1: 8 , sedangkan terendah pada perlakuan pemasakan rumput laut dalam larutan $\mathrm{KOH} 6 \%$ dengan rasio rumput laut dan larutan $\mathrm{KOH}$ 1:12. Hasil uji statistik menunjukkan adanya perbedaan yang nyata antar perlakuan baik perlakuan konsentrasi $\mathrm{KOH}$ maupun rasio rumput laut : larutan $\mathrm{KOH}$. Pada rasio rumput laut : larutan $\mathrm{KOH} 1: 8$, nilai rendemen cenderung meningkat paralel dengan perlakuan konsentrasi larutan $\mathrm{KOH}$ yang diberikan, namun pada rasio rumput laut : larutan $\mathrm{KOH}$ 1:12 cenderung berfluktuasi (Gambar 1)
Perlakuan dengan larutan $\mathrm{KOH}$ menghasilkan rendemen yang tinggi sebab kation $\mathrm{K}^{+}$dari $\mathrm{KOH}$ akan bersenyawa dengan rangkaian polimer karaginan membentuk $k$-karaginan sehingga akan memberikan tambahan berat pada rendemen karaginan yang dihasilkan. Lama ekstraksi dan suhu serta konsentrasi larutan $\mathrm{KOH}$ yang diberikan juga mempengaruhi rendemen karaginan. Nilai rendemen karaginan kertas yang rendah ditemukan pada perlakuan pemasakan dalam larutan $\mathrm{KOH} 4 \%$, rasio rumput laut berbanding larutan $\mathrm{KOH} 1: 8$ yakni sebesar $24,5 \%$ dan perlakuan pemasakan dalam larutan $\mathrm{KOH} 6 \%$ dengan rasio rumput laut dan larutan $\mathrm{KOH} 1: 12$ sebesar $23,9 \%$. Peningkatan rendemen dalam penelitian ini selain dipengaruhi oleh perlakuan larutan $\mathrm{KOH}$ juga dipengaruhi oleh penambahan garam $\mathrm{KCl}$ sebesar $0,1 \%(b / v)$ yang ditambahkan pada saat proses penjendalan filtrat rumput laut. Tujuannya untuk meningkatkan kekuatan gel karaginan kualitas pangan yang dihasilkan. Kadar air awal rumput laut juga berpengaruh terhadap rendemen karaginan yang dihasilkan. Pada penelitian ini kadar air rumput laut kering dari petani setelah dilakukan pengeringan ulang sekitar 35\%. Suryaningrum et al. (1991) menemukan rendemen karaginan rumput laut asal Kabupaten Sumenep Madura sebesar $19,6 \%$ dengan kadar air

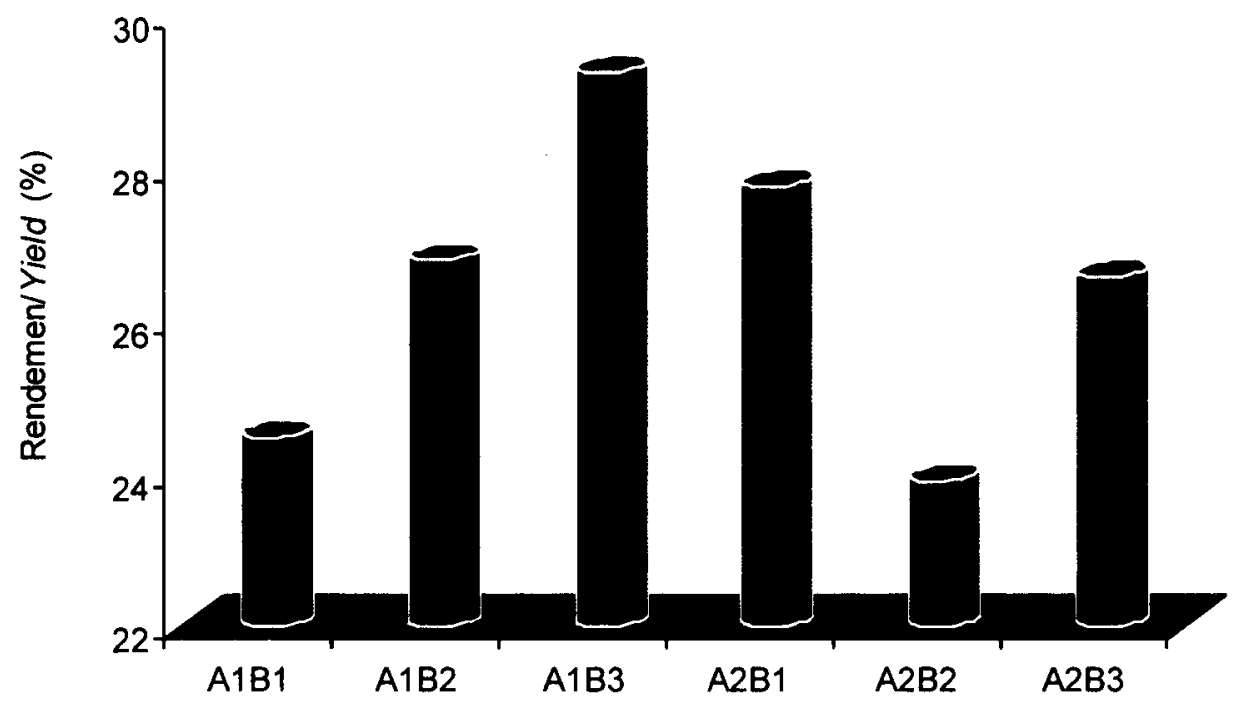

Perlakuan/Treatments

Catatan/Notes: A1 (rasio rumput laut : Iarutan $\mathrm{KOH}=1: 8$ )/ratio of seaweed to $\mathrm{KOH}$ solution = 1:8); A2 (rasio rumput laut : Iarutan $\mathrm{KOH}=1: 12$ )/ratio of seaweed to $\mathrm{KOH}$ solution =1:12);

$\mathrm{B1}$ ( konsentrasi larutan $\mathrm{KOH} 4 \% / \mathrm{KOH}$ concentration of $4 \%$ );

B2 (konsentrasi larutan $\mathrm{KOH} 6 \% / \mathrm{KOH}$ concentration of $6 \%$ );

$\mathrm{B} 3$ (konsentrasi larutan $\mathrm{KOH} 12 \% / \mathrm{KOH}$ concentration of $12 \%$ ).

Gambar 1. Rendemen $k$-karaginan dari berbagai perlakuan konsentrasi $\mathrm{KOH}$.

Figure 1. Yield of $k$-carrageenan extracted by using various concentrations of $\mathrm{KOH}$. 
rumput laut $35,2 \%$, sedangkan dari hasil penelitian ini rendemen yang dihasilkan di atas rata-rata yang dilaporkan pada penelitian Suryaningrum et al. (1991). Istini \& Zatnika (1991) menyatakan bahwa peningkatan konsentrasi larutan $\mathrm{KOH}$ dapat meningkatkan rendemen karaginan. Dari hasil penelitian terbukti bahwa rendemen meningkat sesuai dengan peningkatan konsentrasi larutan $\mathrm{KOH}$ yang diberikan.

\section{Kadar Air}

Nilai kadar air tepung karaginan yang dihasilkan berkisar antara $8,2 \%-9,7 \%$. Nilai kadar air terendah ditemukan pada pemasakan dalam larutan $\mathrm{KOH} 6 \%$ dengan rasio rumput laut dan larutan $\mathrm{KOH}$ 1:12, sebesar $8,2 \%$, dan tertinggi pada perlakuan pemasakan dalam larutan $\mathrm{KOH} 12 \%$ dengan rasio rumput laut dan larutan $\mathrm{KOH} 1: 12$, sebesar 9,7\% (Gambar 2).

Perlakuan ekstraksi karaginan menggunakan kombinasi $\mathrm{KOH}$ dan $\mathrm{KCl}$ menghasilkan kadar air yang lebih rendah karena kation $\mathrm{K}^{+}$yang berasal dari senyawa $\mathrm{KOH}$ dan $\mathrm{KCl}$ mampu mengikat gugus sulfat yang mempunyai sifat hidrofilik (suka air), sehingga proses pengeringan karaginan menjadi lebih cepat. Adanya $\mathrm{K}^{+}$dalam polimer karaginan akan menyebabkan terbentuknya agregasi sehingga polimer tidak banyak menyerap air. Pada perlakuan rasio rumput laut : jumlah larutan $\mathrm{KOH}$ 1:8 kadar air yang dihasilkan di dalam karaginan berfluktuasi, tetapi sebaliknya pada perlakuan rasio rumput laut : jumlah larutan $\mathrm{KOH}$ 1:12 penurunan kadar air berbanding terbalik dengan konsentrasi larutan $\mathrm{KOH}$ yang diberikan yakni nilai terendah kadar air justru diperoleh pada perlakuan larutan $\mathrm{KOH} 6 \%$.

\section{Kadar Abu}

Rumput laut merupakan bahan dasar industri yang mengandung mineral tinggi seperti $\mathrm{Na}^{+}, \mathrm{K}^{+}, \mathrm{Ca}^{2+}$ dan $\mathrm{Mg}^{2+}$. Abu dalam bahan pangan adalah sisa organik yang berupa mineral kering dari bahan yang telah dipanaskan hingga $500^{\circ} \mathrm{C}-600^{\circ} \mathrm{C}$. Beberapa mineral tidak terbakar meskipun dipanaskan hingga $600^{\circ} \mathrm{C}$ seperti kation $\mathrm{Na}^{+}, \mathrm{K}^{+}, \mathrm{Ca}^{2+}$ dan $\mathrm{Mg}^{2+}$ akan dihitung sebagai abu.

Kadar abu yang dihasilkan pada penelitian ini berkisar antara $12,1 \%-15,0 \%$. Nilai terendah

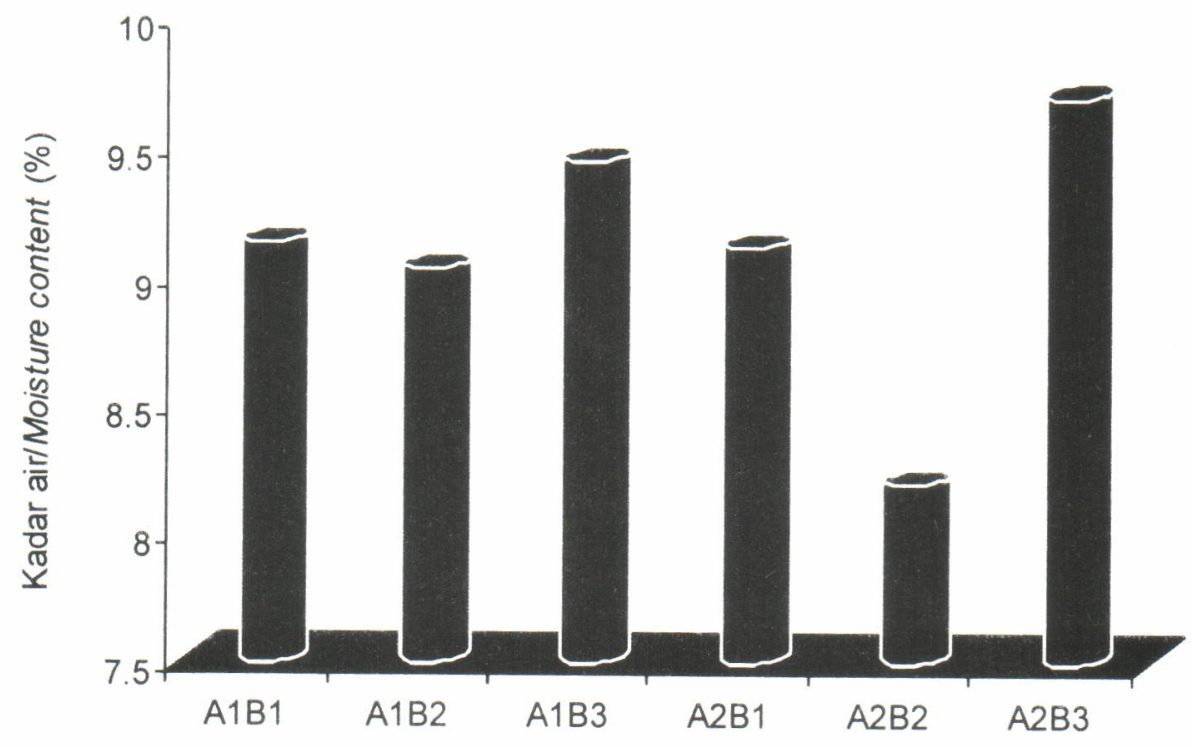

Perlakuan/Treatments

Catatan/Notes: A1 (rasio rumput laut : larutan $\mathrm{KOH}=1: 8$ )/ratio of seaweed to $\mathrm{KOH}$ solution $=1: 8$ );

A2 (rasio rumput laut : larutan $\mathrm{KOH}=1: 12$ )/ratio of seaweed to $\mathrm{KOH}$ solution $=1: 12$ );

$\mathrm{B} 1$ ( konsentrasi larutan $\mathrm{KOH} 4 \% / \mathrm{KOH}$ concentration of $4 \%$ );

B2 (konsentrasi larutan $\mathrm{KOH} 6 \% / \mathrm{KOH}$ concentration of $6 \%$ );

$\mathrm{B} 3$ (konsentrasi larutan $\mathrm{KOH} 12 \% / \mathrm{KOH}$ concentration of $12 \%$ ).

Gambar 2. Kadar air k-karaginan dari berbagai perlakuan konsentrasi $\mathrm{KOH}$.

Figure 2. Moisture content of $k$-carrageenan extracted by using various concentrations of $\mathrm{KOH}$. 


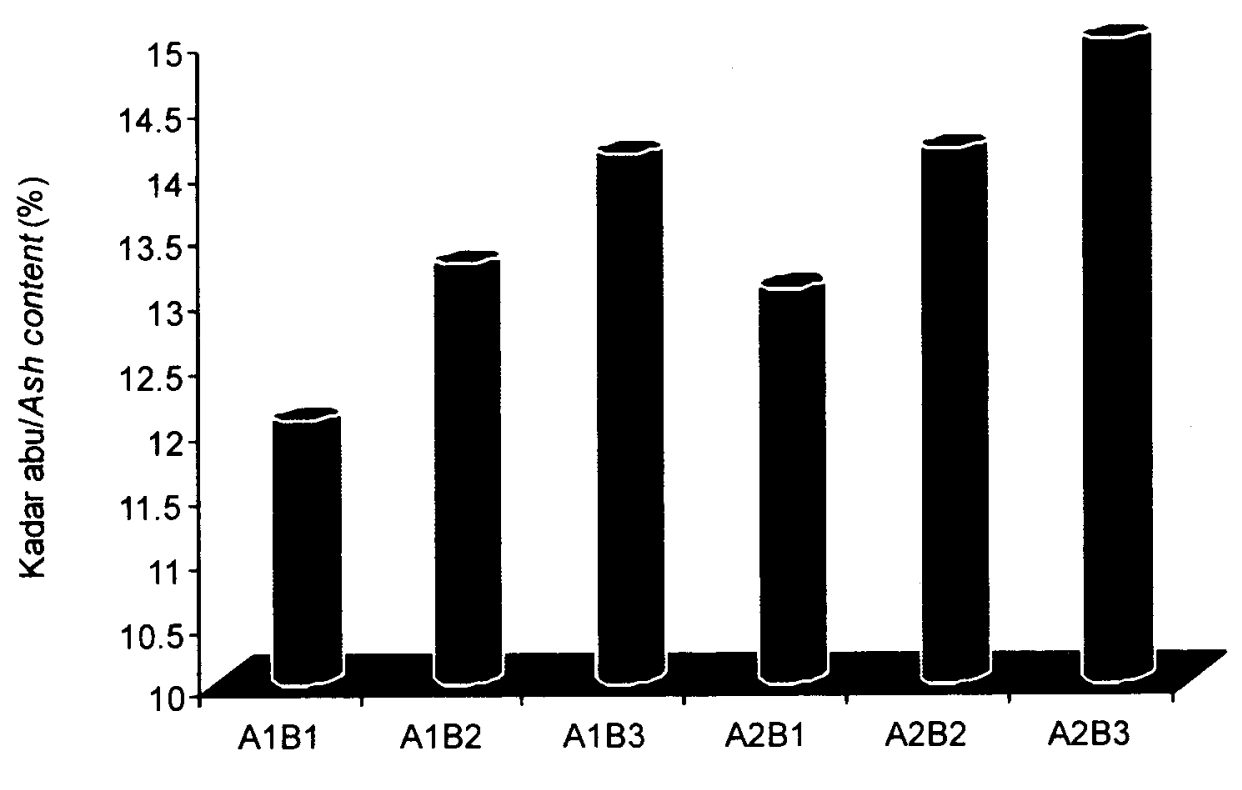

Perlakuan/Treatments

\begin{abstract}
Catatan/Notes: A1 (rasio rumput laut : larutan $\mathrm{KOH}=1: 8$ )/ratio of seaweed to $\mathrm{KOH}$ solution $=1: 8$ ); A2 (rasio rumput laut : larutan $\mathrm{KOH}=1: 12$ )/ratio of seaweed to $\mathrm{KOH}$ solution = 1:12); $\mathrm{B} 1$ ( konsentrasi larutan $\mathrm{KOH} 4 \% / \mathrm{KOH}$ concentration of $4 \%$ );

$\mathrm{B} 2$ (konsentrasi larutan $\mathrm{KOH} 6 \% / \mathrm{KOH}$ concentration of $6 \%$ );

$\mathrm{B} 3$ (konsentrasi larutan $\mathrm{KOH} 12 \% / \mathrm{KOH}$ concentration of $12 \%$ ).
\end{abstract}

Gambar 3. Kadar abu k-karaginan dari berbagai perlakuan konsentrasi $\mathrm{KOH}$. Figure 3. Ash content of $k$-carrageenan extracted by using various concentrations of $\mathrm{KOH}$.

ditemukan pada perlakuan pemasakan rumput laut di dalam larutan $\mathrm{KOH} 4 \%$ dengan rasio rumput laut dan larutan $\mathrm{KOH} 1: 8$ yakni sebesar $12,1 \%$, sedangkan tertinggi diperoleh pada perlakuan pemasakan rumput laut dalam larutan $\mathrm{KOH} 12 \%$ dengan rasio rumput laut dan larutan 1:12 sebesar 15,0\%. Antar perlakuan dan interaksinya menunjukkan perbedaan yang nyata pada taraf $5 \%$ terhadap kadar abu karaginan. Peningkatan kadar abu adalah paralel dengan peningkatan konsentrasi $\mathrm{KOH}$ yang diberikan selama perlakuan. Larutan $\mathrm{KOH}$ telah menyebabkan kation $\mathrm{K}^{+}$bereaksi dengan karaginan membentuk $k$ karaginan sehingga menghasilkan kadar abu yang tinggi. Pada perlakuan konsentrasi $\mathrm{KOH} 4 \%$ menghasilkan nilai kadar abu terendah, hal ini disebabkan kemungkinan jumlah kation $\mathrm{K}^{+}$yang bereaksi dengan karaginan lebih sedikit dibandingkan dengan perlakuan konsentrasi $\mathrm{KOH}$ yang lebih tinggi. Sebagai perbandingan kadar abu yang dihasilkan oleh Mukti (1987) dengan alkohol sebagai bahan pengendap berkisar antara $18,7-20,8 \%$ dan yang diperoleh Luthfy (1988) sebesar 31,4\%. Penelitian Suryaningrum et al. (1991) melaporkan bahwa kadar abu pada karaginan adalah sebesar $21,7 \%$ dengan menggunakan alkohol sebagai bahan pengendap. Dibandingkan dengan hasil yang telah didapat oleh peneliti terdahulu, kadar abu pada penelitian ini jauh lebih kecil yang berarti ada perbaikan kualitas karaginan yang dihasilkan. Hal ini mungkin disebabkan adanya perbedaan teknik pengolahan. Pada percobaan ini rumput laut telah mendapatkan perlakuan alkali panas. Salah satu tujuan proses alkali panas adalah mereduksi bahan-bahan lain selain karaginan di dalam thallus rumput laut. Pada Gambar 3 dapat dilihat kadar abu karaginan yang telah diperlakukan dengan larutan $\mathrm{KOH}$.

\section{Kadar Abu Tak Larut Asam}

Nilai kadar abu tak larut asam yang dihasilkan pada penelitian ini berkisar antara $0,1-0,2 \%$, nilai terendah ditemukan pada perlakuan pemasakan pada larutan $\mathrm{KOH} 12 \%$ dengan rasio rumput luat dan volume larutan $\mathrm{KOH} \mathrm{1:8,} \mathrm{sedangkan} \mathrm{tertinggi} \mathrm{pada}$ perlakuan pemasakan dalam larutan $\mathrm{KOH} 4 \%$ dengan rasio rumput laut dan volume larutan $\mathrm{KOH} \mathrm{1:12.}$ 
Namun demikian semua nilai kadar abu tak larut asam di bawah ketentuan yang ditetapkan oleh FCC (1981) yakni maksimal $1 \%$. Kadar abu tak larut asam yang tinggi di dalam suatu produk menunjukkan adanya kontaminasi dari luar baik dalam proses pengolahan maupun dalam proses lainnya.

Adanya perbedaan nilai kadar abu tak larut asam disebabkan oleh adanya mineral tidak larut asam yang mencemari produk karaginan dengan kadar yang berbeda, sehingga menghasilkan nilai kadar abu tak larut asam yang berbeda pula. Pada Gambar 4 dapat dilihat perbedaan kadar abu tak larut asam pada masing-masing perlakuan. Perlakuan yang berperanan dalam penentuan nilai kadar abu tak larut asam pada penelitian ini adalah rasio rumput laut dan volume larutan $\mathrm{KOH}$. Penggunaan rasio rumput laut dan volume larutan $\mathrm{KOH}$ 1:12 cenderung mempunyai kadar abu tak larut asam meningkat sesuai dengan konsentrasi larutan $\mathrm{KOH}$ yang diberikan. Oleh sebab itu kemungkinan kontaminasi disebabkan oleh penggunaan $\mathrm{KOH}$, karena $\mathrm{KOH}$ yang digunakan adalah $\mathrm{KOH}$ teknis dengan tingkat kemurniannya $98 \%$.

\section{Kadar Sulfat}

Baik rumput laut penghasil agar, maupun penghasil karaginan mengandung gugus sulfat $\left(\mathrm{OSO}_{3}^{-}\right)$yang merupakan salah satu faktor penentu kualitas produk rumput laut. Kadar sulfat yang ditetapkan oleh FCC (1981) berkisar antara 18-40\%. Karaginan hasil ekstraksi dari rumput laut jenis E.cottonii asal Kabupaten Sumenep ini diidentifikasi sebagai $k$ karaginan, hal ini disebabkan teknik ekstraksi menggunakan kation $\mathrm{K}^{+}$yang akan mengubah $\mu$ karaginan menjadi $k$-karaginan. Hasil penelitian menunjukkan bahwa nilai kadar sulfat untuk semua perlakuan berkisar antara 17,4\%-18,6\% (Gambar 5). Nilai kadar sulfat tertinggi ditemukan pada perlakuan pemasakan dalam larutan $\mathrm{KOH} 6 \%$ dengan rasio rumput laut dan volume larutan $\mathrm{KOH} 1: 8$, sedangkan terendah ditemukan pada perlakuan pemasakan dalam larutan $\mathrm{KOH} 12 \%$ dengan rasio rumput laut dan vo-

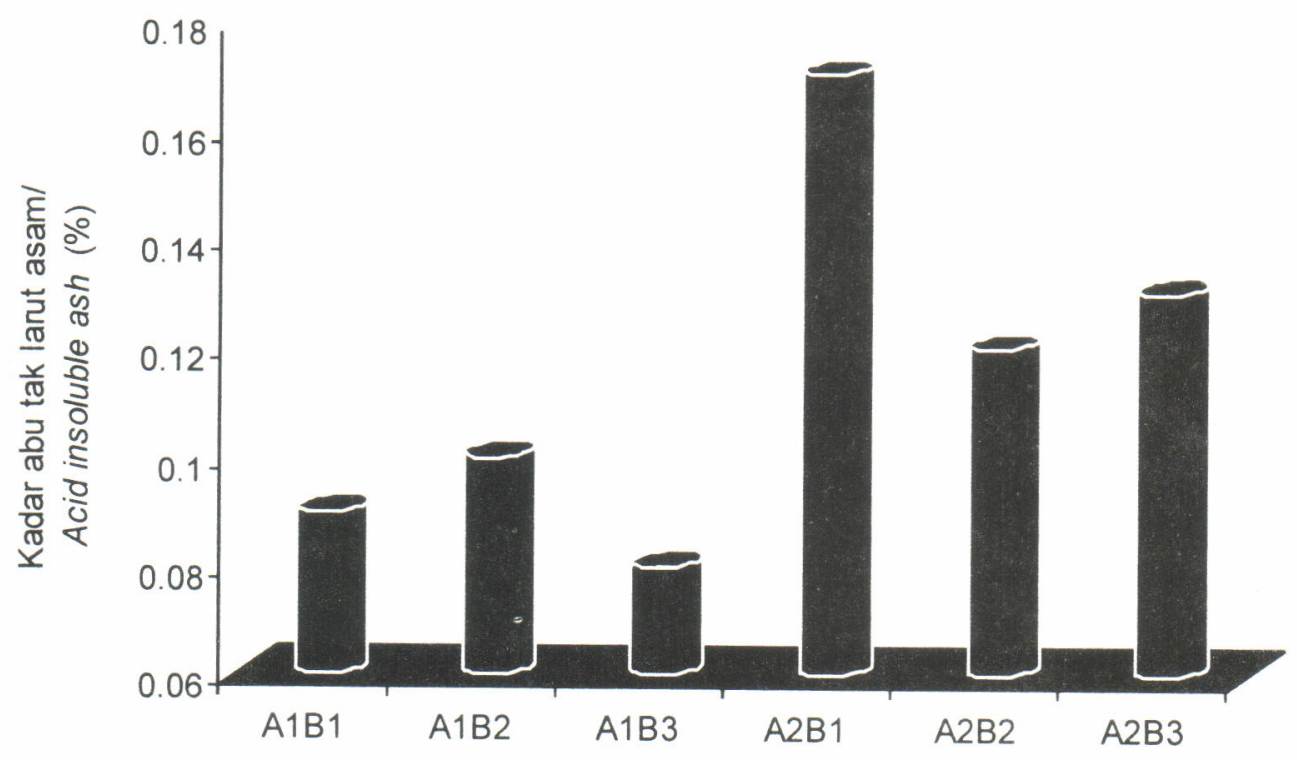

Perlakuan/Treatments

Catatan/Notes: $\mathrm{A} 1$ (rasio rumput laut : Iarutan $\mathrm{KOH}=1: 8$ )/ratio of seaweed to $\mathrm{KOH}$ solution $=1: 8$ );

A2 (rasio rumput laut : larutan $\mathrm{KOH}=1: 12$ )/ratio of seaweed to $\mathrm{KOH}$ solution $=1: 12$ );

$\mathrm{B} 1$ ( konsentrasi larutan $\mathrm{KOH} 4 \% / \mathrm{KOH}$ concentration of $4 \%$ );

$\mathrm{B} 2$ (konsentrasi larutan $\mathrm{KOH} 6 \% / \mathrm{KOH}$ concentration of $6 \%$ );

B3 (konsentrasi larutan $\mathrm{KOH} 12 \% / \mathrm{KOH}$ concentration of $12 \%$ ).

Gambar 4. Kadar abu tak larut asam dalam k-karaginan dari berbagai perlakuan konsentrasi $\mathrm{KOH}$. Figure 4. Acid insoluble ash of $k$-carrageenan extracted by using various concentrations of $\mathrm{KOH}$. 


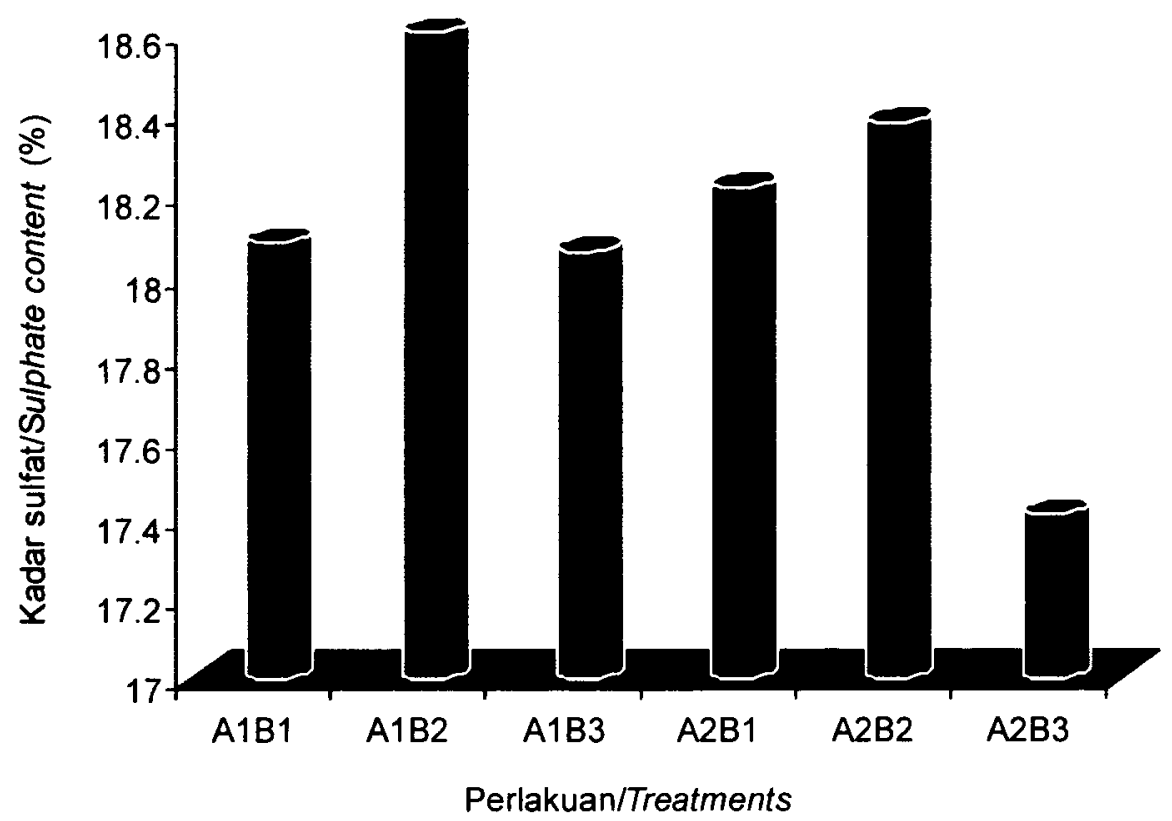

Catatan/Notes:
A1 (rasio rumput laut : larutan $\mathrm{KOH}=1: 8$ )/ratio of seaweed to $\mathrm{KOH}$ solution $=1: 8$ );
A2 (rasio rumput laut : larutan $\mathrm{KOH}=1: 12$ )/ratio of seaweed to $\mathrm{KOH}$ solution $=1: 12$ );
B1 ( konsentrasi larutan $\mathrm{KOH} 4 \% / \mathrm{KOH}$ concentration of $4 \%$ );
B2 (konsentrasi larutan $\mathrm{KOH} 6 \% / \mathrm{KOH}$ concentration of $6 \%$ );
B3 (konsentrasi larutan $\mathrm{KOH} 12 \% / \mathrm{KOH}$ concentration of $12 \%$ ).

Gambar 5. Kadar sulfat $k$-karaginan dari berbagai perlakuan larutan $\mathrm{KOH}$.

Figure 5. Sulphate content of $k$-carrageenan extracted by using various concentrations of $\mathrm{KOH}$.

lume larutan $\mathrm{KOH}$ 1:12 (A2). Namun demikian semua perlakuan menghasilkan nilai kadar sulfat sesuai yang telah ditetapkan oleh FCC (1981).

Hasil penelitian menunjukkan bahwa masingmasing perlakuan mempengaruhi kadar sulfat. Penurunan kadar sulfat dapat dicapai pada penelitian ini dengan memberikan konsentrasi larutan $\mathrm{KOH}$ lebih tinggi. Kation $\mathrm{K}^{+}$akan bereaksi dengan gugus sulfat $\left(\mathrm{OSO}_{3}{ }^{-}\right.$) membentuk $\mathrm{K}_{2} \mathrm{SO}_{4}$ yang larut di dalam air. Tetapi karena gugus sulfat tersebut ada di antara koagulan karaginan sehingga pada saat pemisahan tidak semua gugus sulfat dapat ditarik dari polimer karaginan. Mantell (1947) melaporkan bahwa $\mathrm{Ca}^{2+}$ dapat mengikat gugus sulfat yang terdapat dalam rantai polimer karaginan. Bila rangkaian polimer tersebut ditambah air, maka akan mengakibatkan terlepasnya gugus sulfat dari rangkaian polimer karaginan untuk membentuk $\mathrm{CaSO}_{4}$ dan $\mathrm{H}_{2} \mathrm{SO}_{4}$

Berdasarkan teori ini maka kemungkinan kation $\mathrm{K}^{*}$ juga mempunyai fungsi yang sama dengan kation $\mathrm{Ca}^{2+}$, sebab penggunaan larutan $\mathrm{KOH}$ dalam penelitian ini temyata dapat mereduksi kadar sulfat dalam rumput laut $E$. cottonii dari $28 \%$ menjadi antara $17,4 \%-$ $18,2 \%$.

\section{Kekuatan Gel}

Letak gugus sulfat sangat berpengaruh terhadap pembentukan gel karaginan. Model molekul yang gugus sulfatnya pada atom C-2 yang terikat pada 3,6anhidro-galaktosa terproyeksi keluar sehingga tidak menghalangi pilihan ganda. Sulfat pada atom $\mathrm{C}-4$ yang terikat pada unit D-galaktosa misalnya pada $k$-dan $i$ karaginan juga terproyeksi keluar. Tetapi adanya sulfat pada atom C-6 pada ikatan 1,4 akan mengakibatkan terbentuknya tekukan dalam rantai polimer sehingga menghalangi terbentuknya pilinan ganda (Moirano, 1977). Semakin tinggi kandungan sulfat, kekuatan gel semakin rendah tetapi nilai kekentalan menjadi tinggi.

Hasil penelitian menunjukkan kekuatan gel karaginan berkisar antara $193,34-578,47 \mathrm{~g} / \mathrm{cm}^{2}$. Nilai terendah ditemukan pada perlakuan pemasakan rumput laut di dalam larutan $\mathrm{KOH} 6 \%$ dengan rasio rumput laut dan volume larutan $\mathrm{KOH} 1: 8$, sedangkan tertinggi ditemukan pada perlakuan pemasakan 


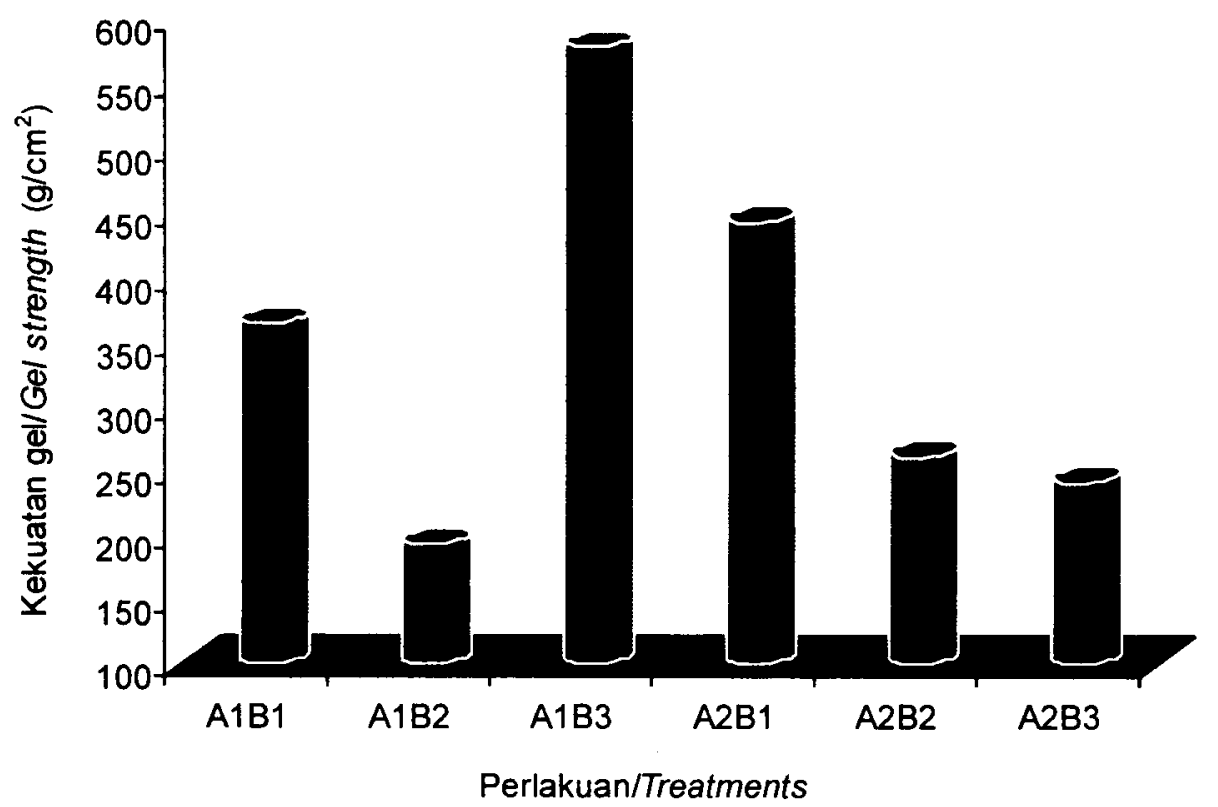
Catatan/Notes: A1 (rasio rumput laut : larutan $\mathrm{KOH}=1: 8$ )/ratio of seaweed to $\mathrm{KOH}$ solution $=1: 8$ ); A2 (rasio rumput laut : larutan $\mathrm{KOH}=1: 12$ )/ratio of seaweed to $\mathrm{KOH}$ solution $=1: 12$ ); $\mathrm{B1}$ ( konsentrasi larutan $\mathrm{KOH} 4 \% / \mathrm{KOH}$ concentration of $4 \%$ ); $\mathrm{B} 2$ (konsentrasi larutan $\mathrm{KOH} 6 \% / \mathrm{KOH}$ concentration of $6 \%$ ); $\mathrm{B} 3$ (konsentrasi larutan $\mathrm{KOH} 12 \% / \mathrm{KOH}$ concentration of $12 \%$ ).

Gambar 6. Kekuatan gel k-karaginan dari berbagai perlakuan konsentrasi $\mathrm{KOH}$.

Figure 6. Gel-strength of $k$-carrageenan extracted by using various concentrations of $\mathrm{KOH}$.

rumput laut di dalam larutan $\mathrm{KOH} 12 \%$ dengan rasio rumput laut dan volume larutan $\mathrm{KOH} 1: 8$. Pada Gambar 6 dapat dilihat nilai kekuatan gel masingmasing perlakuan. Peningkatan kekuatan gel disebabkan oleh adanya daya tarik ionik antara elektro negatif ester sulfat dengan kation tertentu (Rey \& Labuza, 1981). Menurut Towle (1973) karaginan membutuhkan kation tertentu seperti $\mathrm{K}^{+}, \mathrm{Rb}^{+}, \mathrm{Cs}^{+}$dan $\mathrm{NH}_{4}^{+}$dalam mengimbas pembentukan gel.

Gel polisakarida merupakan struktur tiga dimensi yang terbentuk dari larutan polimer. Proses pembentukan gel terjadi karena adanya ikatan antar rantai polimer sehingga membentuk struktur tiga dimensi yang mengandung pelarut pada celahcelahnya. Kation $\mathrm{K}^{+}$dapat berfungsi sebagai bahan pengikat antar rantai polimer karaginan dengan memperkuat struktur tiga dimensi sehingga polimer tersebut akan mempertahankan bentuknya jika dikenai tekanan (Rees, 1969).

\section{Nilai Kekentalan}

Hasil analisis statistik menunjukkan bahwa kekentalan larutan karaginan sangat bervariasi tergantung konsentrasi larutan dan rasio rumput laut dengan jumlah larutan yang diberikan selama proses pemasakan. Nilai kekentalan karaginan yang telah mendapatkan perlakuan berkisar antara 15,0-31,2 cPs, nilai terendah ditemukan pada perlakuan pemasakan rumput laut dalam larutan $\mathrm{KOH} 12 \%$ dengan rasio rumput laut dan volume larutan $\mathrm{KOH}$ $1: 8$, sedangkan nilai kekentalan tertinggi ditemukan pada perlakuan pemasakan rumput laut dalam konsentrasi larutan $\mathrm{KOH} 4 \%$ dengan rasio rumput laut dan volume larutan $\mathrm{KOH}$ 1:12. Nilai kekentalan selain dipengaruhi oleh teknik dan jumlah bahan kimia yang diberikan selama proses ekstraksi juga dipengaruhi oleh temperatur, jenis karaginan, berat molekul dan logam berat yang terkandung di dalam karaginan tersebut (Towel, 1973). Kation divalent seperti $\mathrm{Ca}^{2+}$ dan $\mathrm{Mg}^{2+}$ dapat mempengaruhi nilai kekentalan larutan karaginan. Kation ini diduga terakumulasi pada lingkungan rumput laut yang dibudidayakan. Nilai kekentalan berbanding terbalik dengan kekuatan gel, yakni apabila nilai kekentalan meningkat maka terjadi penurunan nilai kekuatan gel. Hal ini terjadi karena keberadaan gugus sulfat, semakin tinggi kadar sulfat di dalam karaginan maka nilai kekentalan juga semakin tinggi. Pada Gambar 7 dapat dilihat nilai kekentalan karaginan setelah mendapatkan perlakuan. 


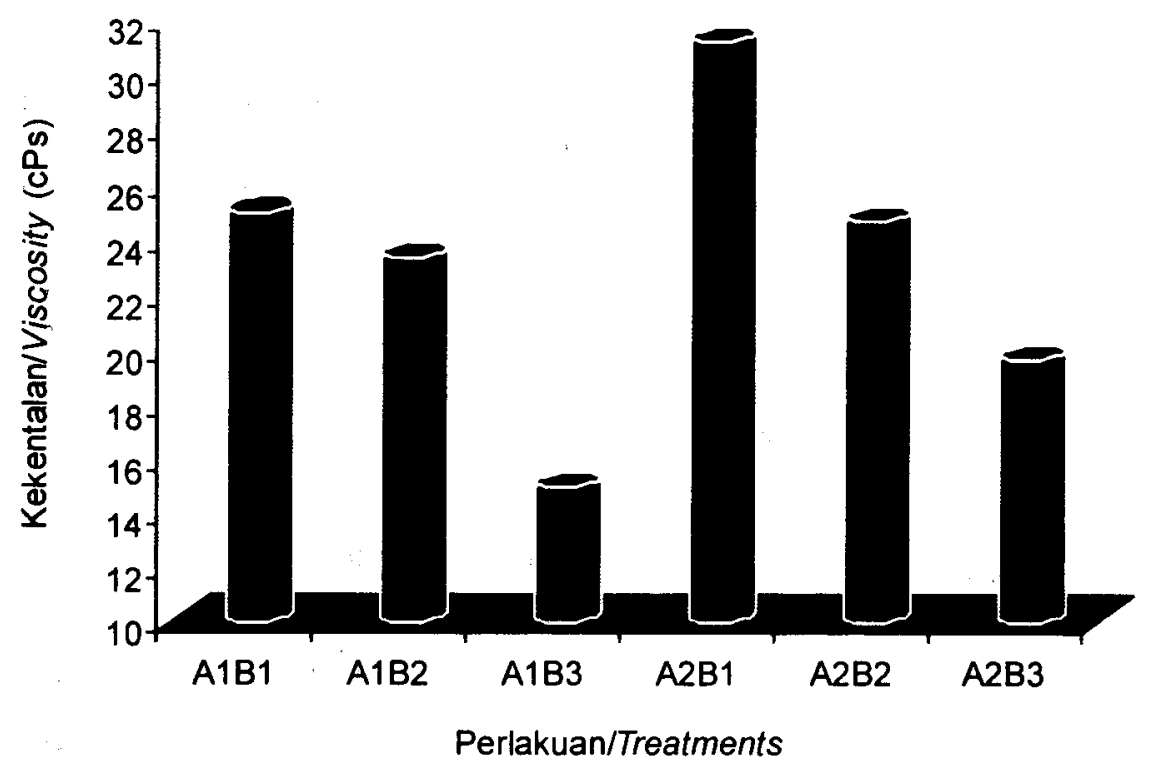

Catatan/Notes: A1 (rasio rumput laut : larutan $\mathrm{KOH}=1: 8$ )/ratio of seaweed to $\mathrm{KOH}$ solution $=1: 8$ ); A2 (rasio rumput laut : larutan $\mathrm{KOH}=1: 12$ )/ratio of seaweed to $\mathrm{KOH}$ solution = $1: 12$ ); $\mathrm{B1}$ ( konsentrasi larutan $\mathrm{KOH} 4 \% / \mathrm{KOH}$ concentration of $4 \%$ ); B2 (konsentrasi larutan $\mathrm{KOH} 6 \% / \mathrm{KOH}$ concentration of $6 \%$ ); $\mathrm{B} 3$ (konsentrasi larutan $\mathrm{KOH} 12 \% / \mathrm{KOH}$ concentration of $12 \%$ )

Gambar 7. Nilai kekentalan $k$-karaginan dari berbagai perlakuan konsentrasi $\mathrm{KOH}$ Figure 7. Viscosity value of $k$-carrageenan extracted by using various concentrations of $\mathrm{KOH}$.

Perlakuan pemasakan dalam larutan $\mathrm{KOH} 12 \%$ dengan rasio rumput laut dan volume larutan $\mathrm{KOH}$ 1:8 menghasilkan nilai kekentalan larutan karaginan sebesar $15,0 \mathrm{cPs}$, kemungkinan ini disebabkan sejumlah gugus sulfat $\left(\mathrm{OSO}_{3}{ }^{-}\right)$yang bereaksi dengan kation $\mathrm{K}^{+}$membentuk kalium sulfat dan asam sulfat. Sebaliknya pada perlakuan pemasakan dalam larutan $\mathrm{KOH} \mathrm{4 \%}$ dengan rasio rumput laut dan volume larutan $\mathrm{KOH} \mathrm{1:12} \mathrm{menghasilkan} \mathrm{nilai} \mathrm{kekentalan} \mathrm{larutan}$ karaginan lebih tinggi yakni sebesar 31,2 cPs. Peningkatan nilai kekentalan larutan karaginan ini terjadi disebabkan oleh kation $\mathrm{K}^{+}$yang bereaksi dengan gugus sulfat membentuk mono dan dieter sulfat yang jumlahnya sedikit, sehingga kandungan sulfat dalam polimer karaginan meningkat. Jumlah sulfat yang tinggi dalam polimer karaginan menyebabkan peningkatan nilai kekentalan larutan karaginan.

\section{KESIMPULAN DAN SARAN}

\section{Kesimpulan}

Perlakuan pemasakan rumput laut $E$. cottonii sebelum proses ekstraksi dilakukan dapat meningkatkan kekuatan gel karaginan, menurunkan nilai kekentalan larutan karaginan, menurunkan kadar abu tak larut asam, abu, dan sulfat. Perlakuan terbaik pada penelitian ini ditinjau dari nilai kekuatan gel adalah perlakuan pemasakan rumput laut di dalam larutan $\mathrm{KOH} 12 \%$ dengan rasio rumput laut dan volume larutan $\mathrm{KOH} 1: 8$ yang menghasilkan karaginan dengan kekuatan gel sebesar $578,5 \mathrm{~g} / \mathrm{cm}^{2}$, kekentalan 15,0 cPs, kadar sulfat $18,1 \%$, kadar abu tak larut asam $0,9 \%$, kada abu $14,1 \%$, kadar air $9,4 \%$ dan rendemen sebesar $29,3 \%$.

\section{Saran}

Meskipun gel strength karaginan hasil penelitian sebesar $578,5 \mathrm{~g} / \mathrm{m}^{2}$, pasar menginginkan karaginan dengan kekuatan gel karaginan di atas $800 \mathrm{~g} / \mathrm{cm}^{2}$. Untuk itu perlu dilakukan penelitian teknik peningkatan nilai kekuatan gel karaginan dengan memperbanyak kation $\mathrm{K}^{+}$selama proses ekstraksi.

\section{DAFTAR PUSTAKA}

Anonymous. 1986. Specification for Identity and Purity of Certain Food Additives. FAO and Nutrition Paper 34: 22.

Food Chemical Codex. 1981. Carrageenan. National Academy Press, Washington. $75 \mathrm{pp}$. 
Glicksman, M. 1983. Food Hydrocolloid. Vol II. CRC Press, Bocaratin Florida. $183 \mathrm{pp}$.

Honwitzs, W. 1980. Official Method of Analysis. $13^{\text {rd }}$ (ed). Washington D.C. $1018 \mathrm{pp}$

Istini, S. dan Zatnika, A. 1991. Optimasi proses semirefine carrageenan dari rumput laut Eucheuma cottonii. Prosiding Temu Karya IImiah Teknologi Pasca Panen Rumput Laut. Jakarta, 11-12 Maret 1991. p. 87-100.

Luthfy, S. 1988. Mempelajari Ekstraksi Karaginan dengan Metode Semirefine dari Eucheuma cottonii. Fakultas Teknologi Pertanian, Institut Pertanian Bogor, Bogor. 106 pp.

Mantell, C.L. 1947. The Water Soluble Gum in Resin. Reinhuld Publishing Corporation, New York. 105 pp.

Marine Colloid FMC. 1978. Raw Material Test Laboratory Standard Practice. Marine Colloids. Div. Corp. Springfiled. New Jersey, USA. 53 pp.

Moirano, A.L., 1977. Sulphate polysaccharides. In Graham, H.D. (ed). Food Colloids. The AVI Publishing Company Inc. Westport, Connecticut. 381 pp.
Mukti, E.D.W. 1987. Ekstraksi dan Analisa Sifat Fisiko Kimia Karaginan dari Rumput Laut Jenis E. cottonii. Masalah khusus. Fakultas Teknologi Pertanian, Institut Pertanian Bogor, Bogor. 82 pp.

Purba, H.G. 1997. Pengaruh Konsentrasi Tepung Karaginan Eucheuma cottonii terhadap Permen Jelly. Skripsi. Jurusan Teknologi Hasil Perikanan. Fakultas Perikanan, IPB Bogor.

Rees, D.A. 1969. Structure, conformation and mechanism in the formation of polysaccharide gels and networks. J. Adv. in Crab. Chim. and Biochem. 24: 108.

Rey, D.K. and Labuza, T.P. 1981. Characterization of the effect of solution on the water-binding and gel strength properties of carrageenan. J. Food Sci. 46: 786-789.

Suryaningrum. Th.D., Murtini, J.T., dan Erlina, M.D. 1991. Sifat fisiko kimia karaginan dari beberapa lokasi budidaya rumput laut di Indonesia. Prosiding Temu Karya IImiah Teknologi Pasca Panen Rumput Laut. Jakarta, 11-12 Maret 1991. p. 75-82.

Towle, D. 1973. Carrageenan. In Whisler, R.L. (ed). Industrial Gums: Polysaccharides and Their Derivates, Academic Press, New York. 109 pp. 